\title{
Lipoxygenase Activity of Hypodermal- and Middle-mesocarp Tissues from Netted Muskmelon Fruit During Maturation and Storage
}

\author{
Gene Lester \\ Subtropical Agricultural Research Laboratory Agricultural Research Service, U.S. Department of \\ Agriculture, 2301 South International Boulevard, Weslaco, TX 78596 \\ Additional index words. Cucumis melo, fatty acids, electrolyte leakage, enzyme, postharvest, senescence
}

\begin{abstract}
Lipoxygenase (LOX) activity was assayed on hypodermal- and middle-mesocarp tissues from netted muskmelon (Cucumis melo L.) fruit 10, 20, 30, and 40 days postanthesis and after 12 days of storage at 4 or 21C. Highest LOX activity was obtained using a phosphate buffer at $\mathrm{pH} 7$ and $20 \mathrm{C}$. LOX activity was detected only in hypodermalmesocarp (hypodermic) tissue at 30 days postanthesis, and activity increased with fruit age and storage temperature. Antioxidants, which inhibit LOX, were detected only in hypodermic tissue from 10 through 30 days postanthesis fruits. Linoleic plus linolenic free fatty acids, substrates for LOX, in hypodermic tissue had declined at 30 days postanthesis, as did plasma membrane integrity, and both continued to decline in association with increased LOX activity.
\end{abstract}

The enzyme lipoxygenase (EC 1.13.11.12), found in most plant tissues, is of critical importance due to its association with senescence (Marcus et al., 1988). Lipoxygenase involvement in senescence specifically catalyzes the oxidation of cis, cis-1,4pentadiene structures unique to the unsaturated fatty acids linoleic, linolenic, and arachidonic, resulting in the production of free radicals (peroxides) that damage biological membranes (Eskin et al., 1977). Fatty acid hydrolysis of lipids occurs during fruit senesence, resulting $\mathrm{m}$ a pool of free fatty acids (Biale, 1975). Linoleic and linolenic fatty acids, which are specific substrates for lipoxygenase catalyses, are also major constituents of most plant membrane lipids (Simon, 1974). Wang and Baker (1979) showed that linoleic and linolenic are the major fatty acids in Cucumis sativa fruits.

In netted muskmelon, fruit softening and senescence are not associated with cell wall breakdown (Lester and Dunlap, 1985), but are associated with the loss of hypodermal-mesocarp tissue membrane integrity (Lester, 1988). Lipoxygenase possibly may play a significant role in netted muskmelon fruit senescence by free radical perturbation of the plasma membrane, but lipoxygenase activity in muskmelon fruit during growth and storage has not been reported.

This paper reports on 1) the presence of lipoxygenase in netted muskmelon fruit, 2) its possible activity in association with linoleic and linolenic free fatty acid content, and 3) its effect on mesocarp plasma membrane permeability during maturation and postharvest storage.

\section{Materials and Methods}

Plant materials. Seeds of 'Perlita' muskmelon were planted and grown in the greenhouse as single plants (Lester and Dunlap, 1985). Flowers were hand-pollinated and one fruit per plant was allowed to develop. Fruits were examined 10, 20, 30, 40, and 50 days after pollination. Muskmelon fruit designated as 50 days postanthesis were harvested at 38 days postanthesis at "full-slip" maturity and stored for 12 days at 4 or $21 \mathrm{C}$ in $85 \%$ $\pm 5 \%$ RH.

Received for publication 21 July 1989. Mention of a proprietary product does not constitute endorsement or recommendation for use by the USDA. The cost of publishing this paper was defrayed in part by the payment of page charges. Under postal regulations, this paper therefore must be hereby marked advertisement solely to indicate this fact.
Electrolyte leakage. Membrane permeability was determined by electrolyte leakage on 20 middle-mesocarp or hypodermalmesocarp tissue disks $(10 \times 1 \mathrm{~mm})$ according to Simon (1977), as modified by Lester and Bruton (1986). The middle-mesocarp disks were from plugs of tissue taken from the center of the mesocarp of whole fruit, and the hypodermal-mesocarp disks were from plugs of tissue taken from within $5 \mathrm{~mm}$ under the epidermis. The disks were rinsed in distilled water $(21 \mathrm{C})$, and leakage was calculated based on the conductivity of electrolytes that had leaked from the tissue disks into a 20-ml water bathing solution after $1 \mathrm{hr}$ of soaking at $21 \mathrm{C}$. Data were expressed as a percentage of the conductivity of total electrolytes in $20 \mathrm{ml}$ after homogenization with the bathing solution and filtration.

Fatty acid determination. Total free fatty acids from $1 \mathrm{~g}$ of fresh weight hypoderrnal-mesocarp tissue or $10 \mathrm{~g}$ of fresh weight middle-mesocarp tissue were extracted according to Folch et al. (1957). Mesocarp tissues were homogenized in $100 \mathrm{ml}$ of 2 chloroform : 1 methanol (v/v), filtered through two layers Miracloth (Calbiochem, La Jolla, Calif.), brought up to $200 \mathrm{ml}$ with $2 \mathrm{CHCl}_{3}: 1 \mathrm{MeOH}(\mathrm{v} / \mathrm{v})$, then $40 \mathrm{ml}$ of $0.04 \% \mathrm{CaCl}_{2}$ was added, and the solution was mixed well and allowed to stand at $4 \mathrm{C}$ for $16 \mathrm{hr}$. Lower phase material was collected, dried over $\mathrm{Na}_{2} \mathrm{SO}_{4}$, evaporated to dryness under $\mathrm{N}_{2}$, then redissolved in four drops of $\mathrm{CHCl}_{3}$ and spotted on a nonactivated silica gel $\mathrm{G}$ plate (Analabs, Norwalk, Conn.) along with linoleic acid standard. Plates were developed with a solvent of $4 \mathrm{CHCl}_{3}: 1$ $\mathrm{MeOH}(\mathrm{v} / \mathrm{v})$ held at $21 \mathrm{C}$ in filter-lined chambers. Free fatty acids were visualized by Rhodamine $6 \mathrm{G}$ using UV light, then scraped from the plates, and methyl esters were prepared by the transesterification $\mathrm{BCl}_{3}-\mathrm{MeOH}$ method of Klopfenstein (1971). Fatty acid methyl esters were analyzed by GC using a Supelcowax 10 (Sulpelco, Bellefonte, Pa.) capillary column $30 \mathrm{~m} \times$ $0.25 \mu \mathrm{m}$ and quantified using methyl heptadecanoate as the internal standard.

Lipoxygenase. The lipoxygenase determination is a modification of Surrey's (1964). Fresh hypodermal-mesocarp or middle-mesocarp tissue (25 g fresh weight) was homogenized with $100 \mathrm{ml}$ of $0.05 \mathrm{M}$ potassium phosphate $(\mathrm{pH} \mathrm{7.0)}$ at $21 \mathrm{C}$ using a Polytron homogenizer (Brinkman, Westbury, N.Y.) equipped with a PTA-50 generating probe. The homogenate was filtered through Miracloth and centrifuged at $4000 \times g$ for $15 \mathrm{~min}$. The supernatant (enzyme solution) was assayed for protein by the method of Bradford (1976). Lipoxygenase activity was deter- 
mined on $1 \mathrm{ml}$ enzyme solution plus $9 \mathrm{ml}$ : $0.5 \mathrm{ml}$ Tween 20, $100 \mathrm{ml} 0.05 \mathrm{M}$ potassium phosphate $(\mathrm{pH} 9.0), 0.5 \mathrm{ml}$ linoleic or oleic acid (control), $1.3 \mathrm{ml} 1 \mathrm{~N} \mathrm{NaOH}$, mixed until the solution was clear and transparent and then was diluted to $200 \mathrm{ml}$ with $0.05 \mathrm{~m}$ potassium phosphate $(\mathrm{pH} \mathrm{5,7,} \mathrm{or} \mathrm{9)} \mathrm{and} \mathrm{further}$ adjusted to $\mathrm{pH} 5,7$, or 9 with concentrated $\mathrm{HCl}$ or $\mathrm{NaOH}$. The linoleic and oleic acids were $100 \%$ pure (Sigma, St. Louis). The combined enzyme-substrate solution was mixed and flushed continuously with $\mathrm{O}_{2}$ for $10 \mathrm{~min}$ at 20C. Then $1 \mathrm{ml}$ of the enzyme-substrate reaction solution was combined with $2 \mathrm{ml}$ $100 \%$ ethanol, and optical density of the alcoholic solution was determined at $234 \mathrm{~nm}$ against an oleic acid control at the appropriate $\mathrm{pH}$.

Antioxidant determination. Antioxidant activity was a modification of the method of BenAziz et al. (1968). The test solution contained $0.2 \mathrm{ml}$ of $20 \%$ (w/v) soybean lipoxidase (EC 1.13.11.12) (Sigma) in $0.05 \mathrm{~m}$ potassium phosphate $(\mathrm{pH} 7), 0.3$ $\mathrm{ml}$ of either hypodermal-mesocarp or middle-mesocarp enzyme solution $(\mathrm{pH} \mathrm{7)}$, and $2.5 \mathrm{ml}$ of linoleic substrate solution $\mathrm{pH}$ 7 ). The test solution was mixed and flushed continuously with $\mathrm{O}_{2}$ for $10 \mathrm{~min}$ at $20 \mathrm{C}$ and determined for lipoxygenase activity. The blank contained $0.3 \mathrm{ml}$ of $0.05 \mathrm{M}$ potassium phosphate buffer ( $\mathrm{pH} 7$ ) instead of fruit homogenate enzyme solution.

Statistics. Least significant difference was calculated for fruit antioxidant activity, lipoxygenase activity, and free fatty acid content from data tested by analysis of variance. All data are means from six fruit with three assays per fruit.

\section{Results and Discussion}

Electrolyte leakage is a predictive measure of muskmelon fruit maturation, postharvest senescence, and mesocarp membrane permeability (Lester, 1988). Electrolyte leakage data of muskmelon fruit hypodermal-mesocarp (hypodermic) and middle-mesocarp (mesocarp) tissue increased with maturation and postharvest storage time (Fig. 1). Mesocarp electrolyte leakage was similar to that of hypodermal tissue at 10 days postanthesis, but, by 20 days, a significant increase occurred only in mesocarp tissue. By 30 days, when netted muskmelon fruit are physiologically mature (Lester and Dunlap, 1985), electrolyte leakage of mesocarp tissue was essentially $100 \%$, indicating that these tissues were senescent. Hypodermic tissues did not show a significant increase in electrolyte leakage from 10 days postanthesis until 30 days. At 40 days, there was a significant increase

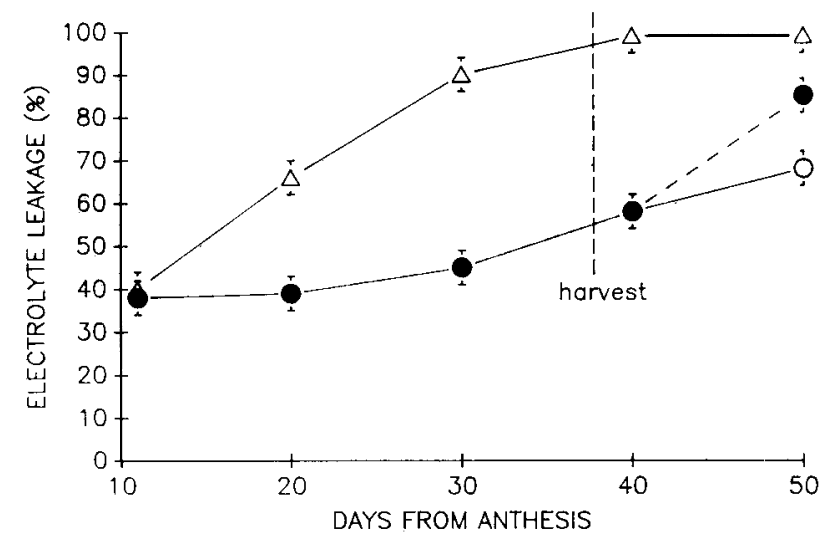

Fig. 1. Efflux of electrolytes into water from hypodermal-mesocarp (hypodermic) and middle-mesocarp (mesocarp; $\Delta$ ) tissues from netted muskmelon fruit $10,20,30,40$, and 50 days postanthesis. The 50-day fruits were harvested 38 days postanthesis and stored for 12 days at $4 \mathrm{C}(\mathrm{O})$ or $21 \mathrm{C}(\mathrm{O})$ and $85 \% \pm 5 \% \mathrm{RH}$. Bars represent sE. in hypodermal electrolyte leakage from 30-day-old tissue, and, by 50 days postanthesis, an additional increase in electrolyte leakage occurred. However, electrolyte leakage was $<100 \%$ at 50 days postanthesis, demonstrating that hypodermic cells in harvested muskmelon fruit are generally intact and metabolic. Also, hypodermic tissue from fruits stored 12 days at $21 \mathrm{C}$ had a significant increase in electrolyte leakage over fruits stored for 12 days at $4 \mathrm{C}$.

Lipoxygenase activity was absent in mesocarp tissue of all maturities of muskmelon fruit tested, whereas, in hypodermic tissue, activity was detected at 30 days postanthesis (Fig. 2). Lipoxygenase activity in hypodermal tissue increased steadily beyond 20 days postanthesis. Lipoxygenase was also highest in the hypodermal/dermal tissues of apple fruit throughout storage, while little or no lipoxygenase activity was detected in the middle-mesocarp tissues (Feys et al., 1980). Lipoxygenase activity in muskmelon fruits stored 12 days at $21 \mathrm{C}$ was higher than that of 40-day postanthesis fruit, while that of fruits stored for 12 days at $4 \mathrm{C}$ did not change significantly. The difference in lipoxygenase activity between fruits stored for 12 days at $4 \mathrm{C}$ and those from $21 \mathrm{C}$ demonstrates that lipoxygenase activity is temperature-dependent. Also, storage of muskmelon fruit at $4 \mathrm{C}$ will limit the energy of activation necessary for optimal oxidation of linoleic and linolenic fatty acids and the eventual production of membrane perturbation peroxides (Eskin et al., 1977).

Lipoxygenase activity from 40-day postanthesis muskmelon fruit was tissue-specific and $\mathrm{pH}$-dependent (Table 1). Mesocarp tissue expressed no lipoxygenase activity, regardless of $\mathrm{pH}$,

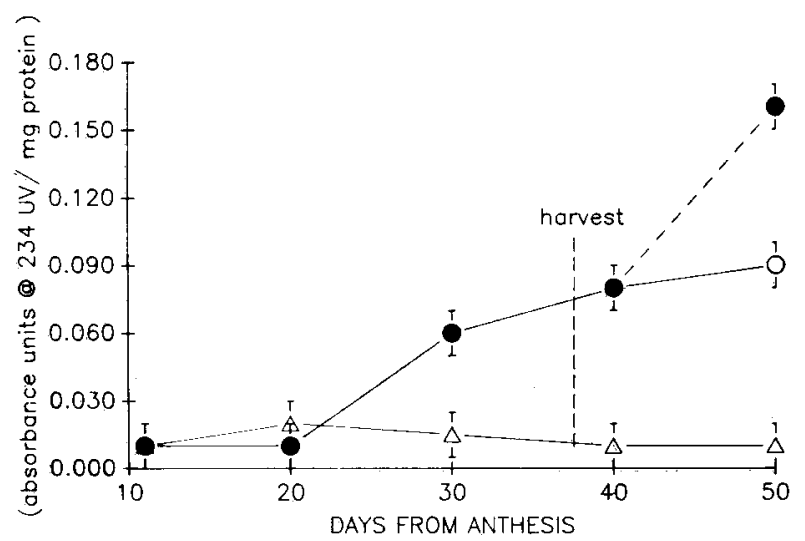

Fig. 2. Lipoxygenase activity in hypodermal-mesocarp (hypodermic) and middle-mesocarp (mesocarp; $\Delta$ ) tissues from muskmelon fruit $10,20,30,40$, and 50 days postanthesis. The 50-day fruits were harvested 38 days postanthesis and stored for 12 days at $4(0)$ ) or $21 \mathrm{C}(\bullet)$ and $85 \% \pm 5 \% \mathrm{RH}$. Bars represent SE.

Table 1. Lipoxygenase activity from 40-day-old muskmelon fruit hypodermal and middle-mesocarp tissue at several $\mathrm{pH}$ values and temperatures. Activity units are expressed as absorbance at $234 \mathrm{~nm} / \mathrm{mg}$ protein for a 10 -min reaction time.

\begin{tabular}{lccc}
\hline \hline $\begin{array}{l}\text { Mesocarp } \\
\text { tissue }\end{array}$ & pH & $\begin{array}{c}\text { Temp } \\
\left({ }^{\circ} \mathrm{C}\right)\end{array}$ & $\begin{array}{c}\text { Absorbance } \\
\text { at 234 nm }\end{array}$ \\
\hline Hypodermal & 5 & 20 & 0.04 \\
& 7 & 20 & 0.11 \\
& 7 & 40 & 0.09 \\
Middle & 9 & 20 & 0.01 \\
& 5 & 20 & 0.01 \\
LSD $=0.05$ & 7 & 20 & 0.01 \\
& 9 & 20 & 0.00 \\
\end{tabular}


whereas hypodermic tissue demonstrated that lipoxygenase activity was present and that the highest activity was found at $\mathrm{pH}$ 7 , with less than half maximal activity at $\mathrm{pH} 5$ and 9 . Rhee and Watts (1966) determined that muskmelon fruit tissue did not have lipid-oxidizing activity; however, they did not describe the fruit tissue assayed and they used an extraction medium buffered at $\mathrm{pH}$ 6.2. It is highly probable that they used the edible mesocarp tissue; thus, this percentage data would confirm their findings. It is unclear why mesocarp tissues express no lipoxygenase activity. This lack of activity suggests that lipoxygenase may not be responsible for senescence of all muskmelon fruit tissues.

Antioxidant activity, expressed as percent inhibition of lipoxygenase activity, was highest at 10 and 20 days postanthesis in the hypodermic, but was not detected in mesocarp tissue (Fig. 3 ). By 30 days postanthesis, inhibition of lipoxygenase activity had declined in the hypodermic to less than half of the inhibition at 20 years postanthesis. By 40 and 50 days postanthesis, there was essentially no inhibition of lipoxygenase activity in the hypodermic. The determination of antioxidants demonstrated that lipoxygenase may be present at all ages of muskmelon fruit hypodermic and that the measurable activity of lipoxygenase in 30-day postanthesis tissue (Fig. 1) is possibly the result of a decline in antioxidants and may not be the result of enzyme do novo synthesis.

The major free fatty acids of both the hypodermic and mesocarp tissues from muskmelon fruit were C16:0, C18:0, C18:1, C18:2, and C18:3 (data not shown). Linoleic (C18:2) and linolenic (C18:3) were the major free fatty acids in 10- through 40-day postanthesis hypodermic tissue (Table 2). Linoleic and linolenic fatty acids, which are substrates for lipoxygenase oxidation, had declined significantly by 30 days postanthesis, which coincides with a significant loss in antioxidants and the onset of lipoxygenase activity. At 40 days postanthesis, there was a decline in the concentration of linoleic plus linoleic free fatty acids in hypodermic tissue, which coincides with an additional increase in lipoxygenase activity. The concentration of linoleic plus linolenic acids continued to decline in storage (50 days postanthesis) (Table 2), while lipoxygenase activity continued to increase. However, in the hypodermic, there was no significant difference at this time in the sum of the acids, either in specific concentration or as a percent of total free fatty acids,

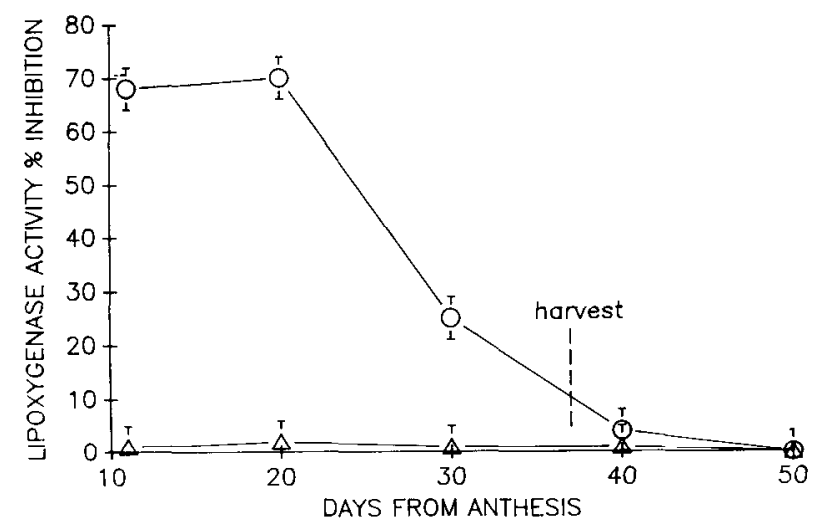

Fig. 3. Antioxidant activity, expressed as percent inhibition of lipoxygenase activity, in hypodermal-mesocarp (hypodermic) and middlemesocarp (mesocarp; $\Delta$ ) tissues from muskmelon fruit 10, 20, 30, 40 , and 50 days postanthesis. The 50-day fruits were harvested 38 days postanthesis and stored for 12 days at $4 \mathrm{C}(\mathrm{O})$ or $21 \mathrm{C}(\mathrm{O})$ and $85 \% \pm 5 \%$ RH. Bars represent SE.
Table 2. Linoleic (C18:2) and linolenic (C18:3) free fatty acid concentration from 10-, 20-, 30-, 40-, and 50-day-old muskmelon fruit hypodermal-mesocarp (hypodermis) and middle-mesocarp (mesocarp) tissue. Fruits were harvested at full slip $(\approx 40$ days from anthesis) and stored at 4 or $21 \mathrm{C}$ in $85 \% \pm 5 \% \mathrm{RH}$.

\begin{tabular}{|c|c|c|c|c|}
\hline \multirow{2}{*}{$\begin{array}{l}\text { Days } \\
\text { from } \\
\text { anthesis }\end{array}$} & \multicolumn{2}{|c|}{$\begin{array}{c}\mathrm{C} 18: 2+\mathrm{C} 18: 3 \\
(\mu \mathrm{g} / \mathrm{g} \text { dry wt })\end{array}$} & \multicolumn{2}{|c|}{$\begin{array}{c}\mathrm{C} 18: 2+\mathrm{C} 18: 3 \text { as a } \\
\text { percentage of } \\
\text { total free fatty acids }\end{array}$} \\
\hline & Hypodermis & Mesocarp & Hypodermis & Mesocarp \\
\hline 10 & 8.2 & 0.9 & 73 & 26 \\
\hline 20 & 10.9 & 1.3 & 85 & 42 \\
\hline 30 & 8.7 & 0.8 & 79 & 49 \\
\hline 40 & 4.9 & 0.4 & 57 & 37 \\
\hline \multicolumn{5}{|c|}{ After 10 days of storage at $4 C$} \\
\hline 50 & 1.4 & 0.5 & 30 & 27 \\
\hline \multicolumn{5}{|c|}{ After 10 days of storage at $21 \mathrm{C}$} \\
\hline 50 & 1.3 & 0.6 & 28 & 37 \\
\hline $\mathrm{LSD}=0.05$ & 0.9 & 0.2 & 8 & 7 \\
\hline
\end{tabular}

between fruit stored at 21 and $4 \mathrm{C}$. Given that the mesocarp tissue is essentially $100 \%$ leaky (senescent) at 30 days postanthesis (Fig. 1), any change in the fatty acid content would be due to respiration, resulting in the breakdown of membrane lipids. With a lower storage temperature (21 vs. 4C), the respiration rate also would decline, thus resulting in the observed difference in the percentage that mesocarp linoleic plus linolenic acid are of the total free fatty acids for fruit held at 4C (27\%) and $21 \mathrm{C}(37 \%)$. However, the reason for C18:2 plus C18:3 fatty acid concentrations being similar in the hypodermic, regardless of storage temperature, could be due to a heightened respiration rate at $21 \mathrm{C}$, generating free fatty acids from the breakdown of membrane lipids and thus replacing those metabolized in stored tissue.

In conclusion, lipoxygenase activity in muskmelon fruit, as demonstrated in these tests, supports Rhee and Watts (1966) in that there is no activity in mesocarp tissue, but that lipoxygenase activity is present in hypodermic tissues of 30-day postanthesis or older fruit. The lack of lipoxygenase activity in muskmelon mesocarp tissue demonstrates that the regulatory mechanisms controlling the breakdown of this tissue is unknown and that lipoxygenase activity, although associated with senescence, may not be associated with the senescence of all tissues. In hypodermic tissue, lipoxygenase appears to play a major role in muskmelon fruit senescence by the possible production of peroxides from the oxidation of free fatty acids, which, in turn, result in the perturbation of membranes. Postharvest netted muskmelon fruit senescence may be controlled by retarding lipoxygenase activity in hypodermal membrane tissues. This control might be accomplished by maintaining, throughout muskmelon fruit maturation and senescence, the antioxidants that inhibit lipoxygenase activity in 20-day-old and younger fruits.

\section{Literature Cited}

BenAziz, A., S. Grossman, P. Budowski, I. Ascarelli, and A. Bondi. 1968. Antioxidant properties of lucerne extracts. J. Sci. Food Agr. 19:605-608.

Biale, J.B. 1975. Synthetic and degradative processes in fruit ripening, p. 5-18. In: N. Haard and D. Salunkhe (eds.). Postharvest biology and handling of fruits and vegetables. AVI, Westport, Conn.

Bradford, M.M. 1976. A rapid and sensitive method for the quantitation of microgram quantities of protein utilizing the principle of protein dye binding. Anal. Biochem. 72:248-254.

Eskin, N.A.M., S. Grossman, and A. Pinsky. 1977. Biochemistry of 
lipoxygenase in relation to food quality. CRC Crit. Rev. Food Sci. Nutr. 9:1-40.

Feys, M., W. Naesens, P. Tobback, and E. Maes. 1980. Lipoxygenase activity in apples in relation to storage and physiological disorders. Photochemistry 19:1009-1011.

Folch, J., M. Lees, and G.H. Slone Stanley. 1957. A simple method for the isolation and purification of total lipids from animal tissues. J. Biol. Chem. 226:497-509.

Klopfenstein, W.E. 1971. On methylation of unsaturated acids using boron trihalide-methanol reagents. J. Lipid Res. 12:773-776.

Lester, G.E. 1988. Comparisons of 'Honey Dew' and netted muskmelon fruit tissues in relation to storage life. HortScience 23:180182.

Lester, G.E. and B.D. Bruton. 1986. Relationship of fruit waterless to netted muskmelon postharvest storage life. J. Amer. Soc. Hort. Sci. 111:727-731.

Lester, G.E. and J.R. Dunlap. 1985. Physiological changes during development and ripening of 'Perlita' muskmelon fruits. Scientia Hort. 26:323-331.

Marcus, L., D. Prusky, and B. Jacoby. 1988. Purification and characterization of avocado lipoxygenase. Photochemistry 27:323-327.

Rhee, K.S. and B.M. Watts. 1966. Evaluation of lipid oxidation in plant tissues. J. Food Sci. 31:664-668.

Simon, E.W. 1974. Phospholipids and plant membrane permeability. New Phytol. 73:377-420.

Simon, E.W. 1977. Leakage from fruit cells in water. J. Expt. Bot. 28:1147-1152.

Surrey, K. 1964. Spectrophotometric determination of lipoxygenase activity. Plant Physiol. 38:65-70.

Wang, C.Y. and J.E. Baker. 1979. Effects of two free radical scavengers and intermittent warming on chilling injury and polar lipid composition of cucumber and sweet pepper fruits. Plant Cell Physiol. 20:243-251 